\title{
The Relationship Between the Public and Private Spaces in Siverek Traditional Settlement
}

\author{
Mazlum Kalak ${ }^{1}$, Rana Karasözen ${ }^{2} \oplus$ \\ ${ }^{1}$ Res. Asst., Architecture Faculty, Gazi University, Ankara, Turkey, E-mail: mazlum_kalak@hotmail.com \\ ${ }^{2}$ Assoc. Prof. Dr., Eskişehir Technical University, Eskişehir, Turkey, E:mail: rkarasozen@eskisehir.edu.tr
}

\begin{abstract}
Purpose

Traditional houses are living spaces that the user shapes over time according to specific environmental factors and needs, which come together in a certain pattern forming some key parts of the traditional settlement texture. This pattern, which also reflects the local culture, is created by the relationships among the public, private, and intermediate spaces. The traditional Siverek architectural settlement is quite rich in such spaces. The main elements that form the urban pattern are the squares and streets that form public spaces, the houses representing the private space, and the in-between spaces such as texture-specific dead-end streets and archways that bridge these two types of spaces. However, due to the uninformed and miscalculated interventions in the original texture, mistimed protection measures, and failure to produce solutions for preservation, these architectural gems are at risk of extinction. At this point, two problems have been identified. The first is the preservation of the historical fabric. Another problem is the incompatibility of the newly planned areas with the old texture and housing layout. The purpose of this study is to provide guidance for new planning by analyzing the spatial arrangement of the traditional Siverek settlement.
\end{abstract}

\section{Design/Methodology/Approach}

In this context, from public spaces to residential private spaces, the spaces and their spatial relationships in the Siverek settlement plan were examined in a hierarchical order. The interrelationships among the spatial elements specific to the original texture of Siverek were discussed, and their status regarding their functional and spatial features in the urban texture were explained.

\section{Findings}

As a result of the study, it is stated that the traditional settlement texture and architecture of Siverek should be documented and preserved. Furthermore, considering the fact that the physical and social components that shape the spatial elements of the traditional fabric remain valid today, the need to transfer spatial formations and spatial hierarchies between public and private spaces to new designs on the settlement scale and building scale was emphasized.

\section{Social/Practical Implications}

It will serve as a guide for consideration in future designs of the city of Siverek, not by imitating traditional forms, but by analyzing spatial setup.

\section{Originality/Value}

This study is the first study on the public and private space relationship in Siverek.

Keywords: Public space, private space, in betwen space, traditional housing, Siverek 


\section{INTRODUCTION}

Siverek is a Mesopotamian settlement in southeastern Turkey that has been home to various civilizations throughout its 7000-year history and has been located on trade routes. (Figure 1).

The traditional settlement of Siverek has a unique organic texture that calls for a careful analysis. With its structure developing organically in and around the castle until the middle of the twentieth century, the settlement is now wedged between the wider and geometric road systems bordered by the zoning islands created by the subsequent zoning arrangements (Figure 2). This has kept increasing the pressure on its traditional texture and accelerated the process of extinction. Although change is inevitable in every living culture and city, managing such a change by taking into account the architectural and urban identity elements is a highly critical issue (Kandemir, 2017, p. 10). In addition, physical conditions and traditional social structure still exist. Today, the spatial formations of these traditional houses, which have been rapidly destroyed because they have not yet been legally protected, are important in terms of transferring cultural continuity to future generations.
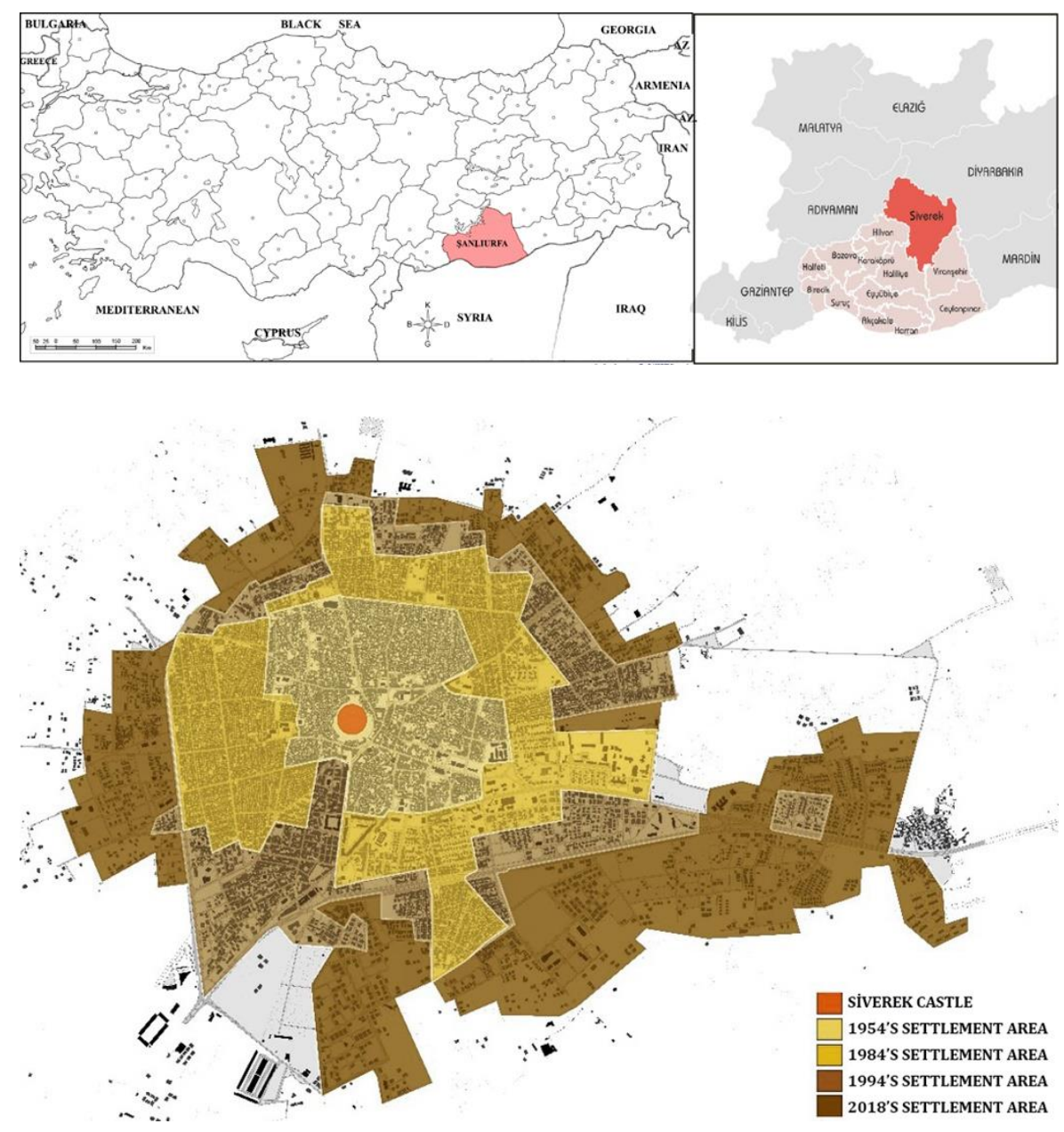

Figure 1. Geographical Location of Siverek District (Kalak, 2018, p.68)

Figure 2. Physical Change of Siverek over the Years (Kalak, 2018, p.63, Sinmaz \& Ahsen Özdemir, 2016, p.27) 
The Relationship Between the Public and Private Spaces in Siverek Traditional Settlement

As a method; In order to define the concepts of public-private and to gather information about the district of Siverek, a wide literature review was conducted. In the original part of the study, Several analyses have been done on the maps (1953, 1954, 1958, 1984, 1994 ) and satellite images of the area $(1961,1986,2005)$ which were taken from the General Map directoryof the Turkey (Harita Genel Komutanlığı) and the change in the space has been pointed on the output maps. In this context, the historical range of the analysis of the traditional texture of the city has been determined within the scope of the data obtained from HGK (Map General Command). In this way, analyzes were made at city scale. Maps were obtained from 'Milli Kütüphane' for smaller scale analysis; The drawings of the work area were obtained from 'Şanlıurfa Metropolitan Municipality' and 'Siverek Municipality' and the necessary data were obtained from 'Şanlıurfa Cultural Heritage Preservation Regional Board Directorate'. With the data obtained, the borders of the traditional texture, which is the study area, were determined and concentrated in the specified area. In this area, the spatial elements shaped in the context of the public-private space of the city have been analyzed. Then, studies were carried out on a housing scale. 55 residences were entered in order to gather information about the houses. A preliminary examination has been made about the spatial formation and elements of the houses. Sketches of the examined houses were drawn, photographs were taken, oral interviews and observations were included.

The objective of this study is to serve as a guide for consideration in future designs of the city of Siverek, not by imitating traditional texture, but by analyzing spatial setup. In this context, the physical and social components that form the settlement are laid out first. The spatial hierarchies from public to private on the urban scale and from common space to private on the residential scale have been analyzed with field and archive research and transformed into schemes that form this network.

\section{FACTORS SHAPING SIVEREK TRADITIONAL SETTLEMENT}

Siverek is located in the region geographically called "Mesopotamia," and is an important settlement that has hosted many civilizations throughout history. The history of the city dates as far back as 50004500 BC, the early Chalcolithic Age (Çelik, 2008, p. 130). It has also been home to various tribes and civilizations such as Uruks, Sumerians, Accadians, Assyrians, Hittites, Romans, Sasanis, Mitannis, Byzantines, Arabs, Seljuks, and Ottomans in various periods (Özgültekin, Akman, Demirbağ, \& Sun, 2003, p. 40-77). The settlement, which has been on important trade routes throughout history, is a vivid trade hub, being located on the highway connecting the two major cities of Şanlıurfa and Diyarbakır (Kalak, 2018, p. 47-52). Preserving its traditional characteristics until the mid-twentieth century, the urban housing structure of the city has been deeply affected by the Master 
Development Plans (1968, 1993, 2004, 2015), which began to be implemented after the migration from rural areas to the city after 1950. Siverek has certain traditional settlement and housing features that are specific to the region. Rapoport defines the traditional residence as the product of folk culture, as an element of an artificial frame that forms the traditional living environments of the society to which it belongs and where architects play almost no role. Traditional settlements and residences where the name of the architect is not known and the architecture belongs to the society rather than the person are called "Anonymous Architecture" (Rapoport, 1969, cited in Eyüce, 2005, p. 6). Many physical and socio-cultural factors have played a part in shaping the traditional Siverek houses and urban fabric.

\section{Physical Factors}

The physical factors that physically shape the city can be considered either as natural or man-made. While the eastern borders of Karacadag and the Euphrates river in the west form the natural borders of the settlement (Akpirinç, 2012, p.1), the geographical and climatic conditions in addition to the Esmer stream running through the city have been some other important natural factors. In addition, the castle in the city center, which was built on a mound during the Assyrian period, has been a key landmark in the city with a flat topographical surface, and the settlement has radially developed around this castle (Figure 3).

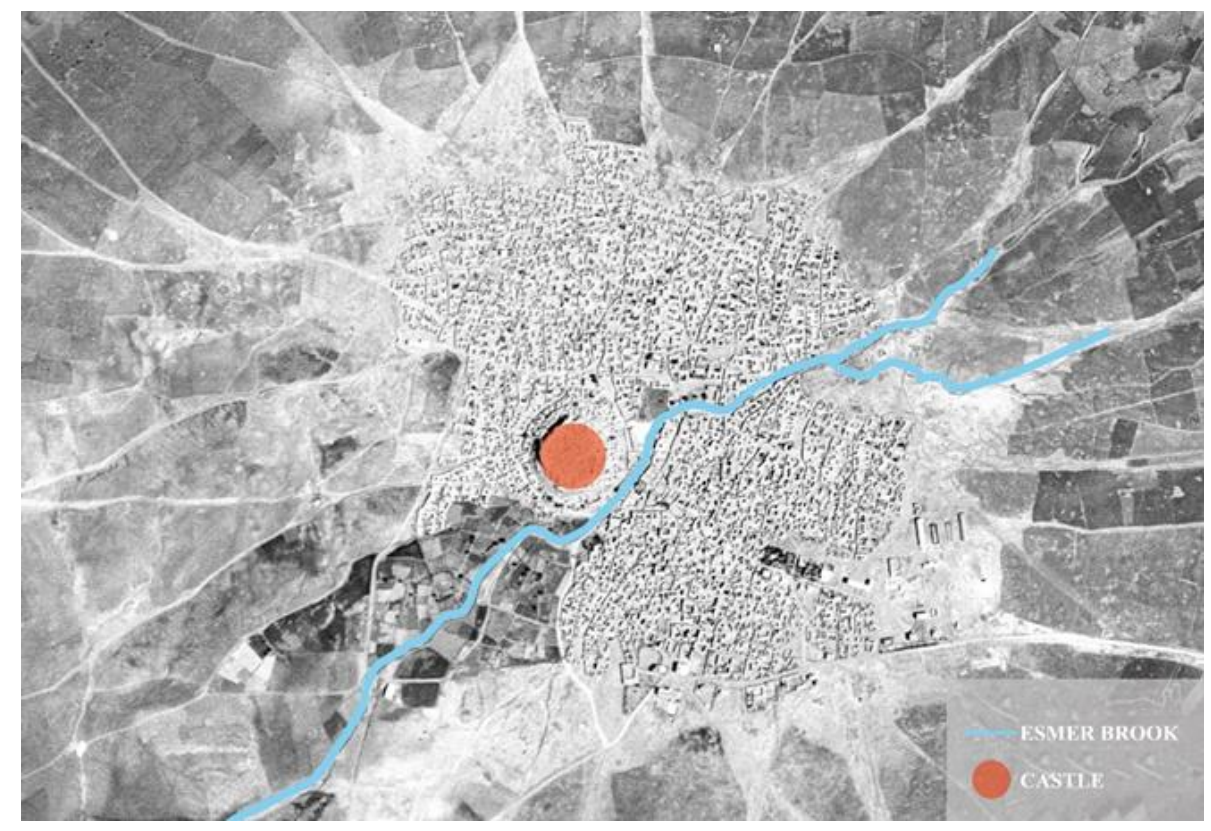

Another critical factor shaping the city has been the climate. Terrestrial steppe climate characteristics are observed in and around Siverek. The warm and dry climate of the city has resulted in the narrow and organic boundaries of the houses formed by the streets (Figure 4). The Siverek houses' being single- or double- storey allows the wind to reach into the
Figure 3. Satellite Image from the year 1954 (Archive of the General Command of Cartography), (Kalak, 2018, p.53) 
The Relationship Between the Public and Private Spaces in Siverek Traditional Settlement

narrow streets in the city, creating more airy spaces. The narrow streets, archways and high walls of the houses create shaded areas on the streets. The warm climate has also led the houses to be structured around a courtyard (Kalak, 2018, p. 50). In addition, the basalt stone, which is the local material that gives the city its characteristic feature, protects the buildings from the heat in the summer and the cold in the winter, thus maintaining the thermal balance in the environment.

Figure 4. General view of the city in 1926 (Siverek Municipality Archive) (Kalak, 2018, p.64)

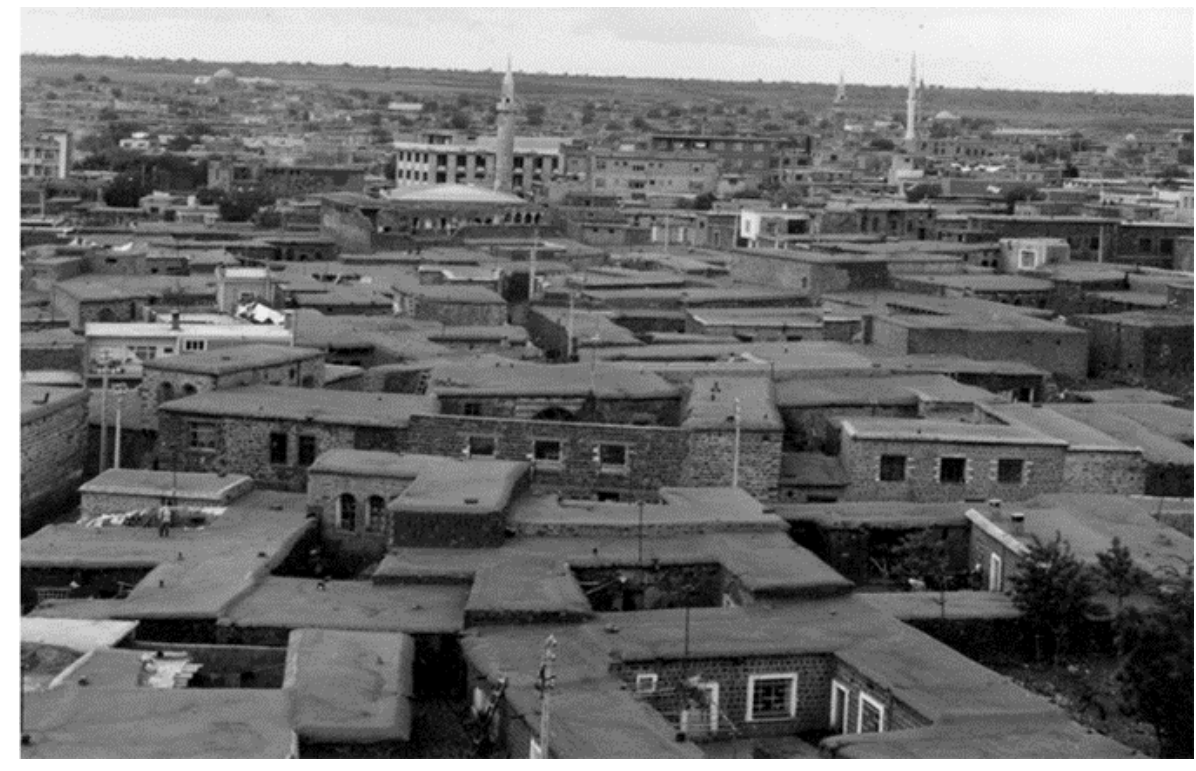

\section{Socio-cultural Factors}

Rapoport discussed the impact of socio-cultural structure on traditional housing under 5 themes as the basic needs, family, position of women, privacy, and social interaction (Rapoport, 1969, p. 61). The society that constitutes the Siverek settlement has a collective structure based on the agricultural economy, consisting of large families with patriarchal order, where women's life is limited to the home and family environment, and the privacy of the family and women is important. The cul-de-sacs, high-walled houses, that the exterior of the houses are usually shut-off, the height of the window openings are above the human eye level, the interior spaces are completely cut off from the outside, and the haremlik-selamlik (separate rooms for men and women) clearly show the importance of privacy. The courtyard used by women as a working and socializing area is a space open only to the rooms and closed to the outside. Winter provisions are prepared by women who gather in the courtyard and the food is dried on the flat adobe roofs of the houses (Kalak, 2018, p. 59).

In Siverek, the family structure is composed of large families in a patriarchal and hierarchical order with tight-knit family and kinship relationships. The elderly individuals respected as the authority at home have the final say about the lifestyle of other family members. This hierarchy is reflected in the house in the form of a special headroom for the elderly individual of the household. It is deemed appropriate for 
multiple families to live together in large houses, consisting of relatives or married children of the household. When the space is too limited to live under the same roof, kinship ties are maintained by living in houses on the same street within close proximity to each other (Kalak, 2018, s. 59).

One of the important factors in shaping settlements is the city's economy and its trade. Siverek has been on an important trade route since ancient times and has become a frequent destination for many civilizations which has led many commercial buildings such as inns, Turkish baths and coffee shops to start their business here, resulting in families with various socio-economic statuses. Families with high economic income have generally resided in mansion-like two-storey structures with cut stones, whereas low-income families resided in single-storey houses. The high-income families' houses have larger guest rooms and other spaces than those of low-income families. While the water needs of the general public are met by common fountains, the high-income families use the wells in their courtyards to meet their water needs. Since there were families who used animals of burden for transportation in the past, barn solutions were also provided in the house. In large families heavily engaged in trade and agriculture, warehouse solutions were also supplied within the housing. However, revised in line with the modern comfort conditions, many original spaces have been removed or altered to serve other functions.

\section{SPATIAL FORMATIONS AND HIERARCHICAL ORDER IN SIVEREK}

The spatial hierarchy is the transition between the human-produced public space and the semi-public, semi-private, and private space, or in other words, the whole set of interrelations, as stated by Sennet. There is a hierarchical order among the spaces that are shaped according to the behavior of people in urban spaces determined by concepts such as occupancy-space, functionality, use, accessibility, and ownership (Erdönmez \& Akl, 2005, p. 67). Although "public" and "private" are usually used as two diametrically opposite concepts, they may occasionally intertwine and emerge as a private space within the public or a public space within the private, which is an issue for heated debate (Gürallar, p. 54).

Examining the factors that affect the shaping of the city of Siverek and the traditional housing structure makes it easier to read the hierarchical spatial order. The city center as the public space and the houses as private spaces are situated separately from each other. The residential districts consist of neighborhoods. These neighborhoods have developed around the sub-centers with their mosques, coffee houses and fountains. The main axes connecting the main center to the lower centers and the capillary-like smaller axes and cul-de-sacs that extend to the houses from these axes form the hierarchical steps between the public and private spaces (Figure 5). Thus, the city of Siverek was examined as public, private and intermediate spaces. 
Figure 5. The relationship among the square, small square, street, and cul-de-sac in traditional Siverek urban structure (Kalak, 2018, p.85)

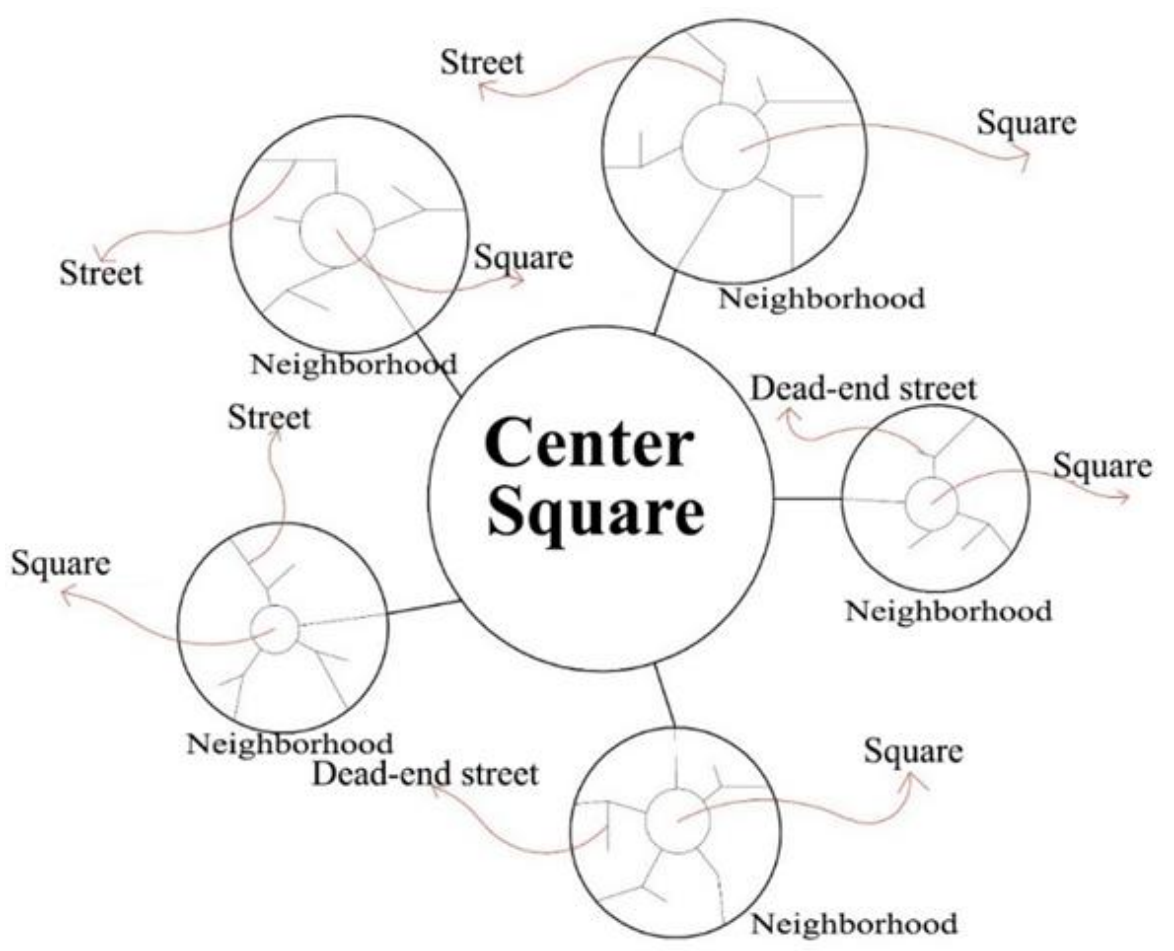

\section{Public Spaces in Siverek}

"Common" areas or the spaces where public use is permitted are the public spaces where everyone can be "seen and heard." Public space is labeled as "accessible," that is, as groups of buildings that allow general use or urban open spaces. Being public for buildings can be defined by accessibility, not ownership. Urban/public open spaces are spaces, parks, squares, and streets open for everybody's use (Gürallar, 2009, p. 54). Public space is a common ground in which social or individual activities are carried out, whether in everyday life or during special times such as festivals (Madanipour, 1996). The analysis of the elements that make up public spaces is important since it serves as a guide for urban development. Public spaces that form the formal language of the city are organized in a hierarchical way to ensure distribution and circulation to the city (Gökgür, 2008, p. 79 \& Karaman, 1991, p. 31).

In Siverek, the city center is the biggest public space with the mosques, Turkish baths, inns, coffee shops, bazaars, and markets located here. (Kalak, 2018, p. 53). When the location of the city center was examined, it was seen that the castle is located on the eastern outskirts and there are many inns and baths in the area extending to the southern perimeter of the city. In addition, there are accommodation inns at the southern end of the settlement, although separate from the center. This points to the route through which the caravan routes pass, and shows that the city center was formed according to this route (Figure 6). 


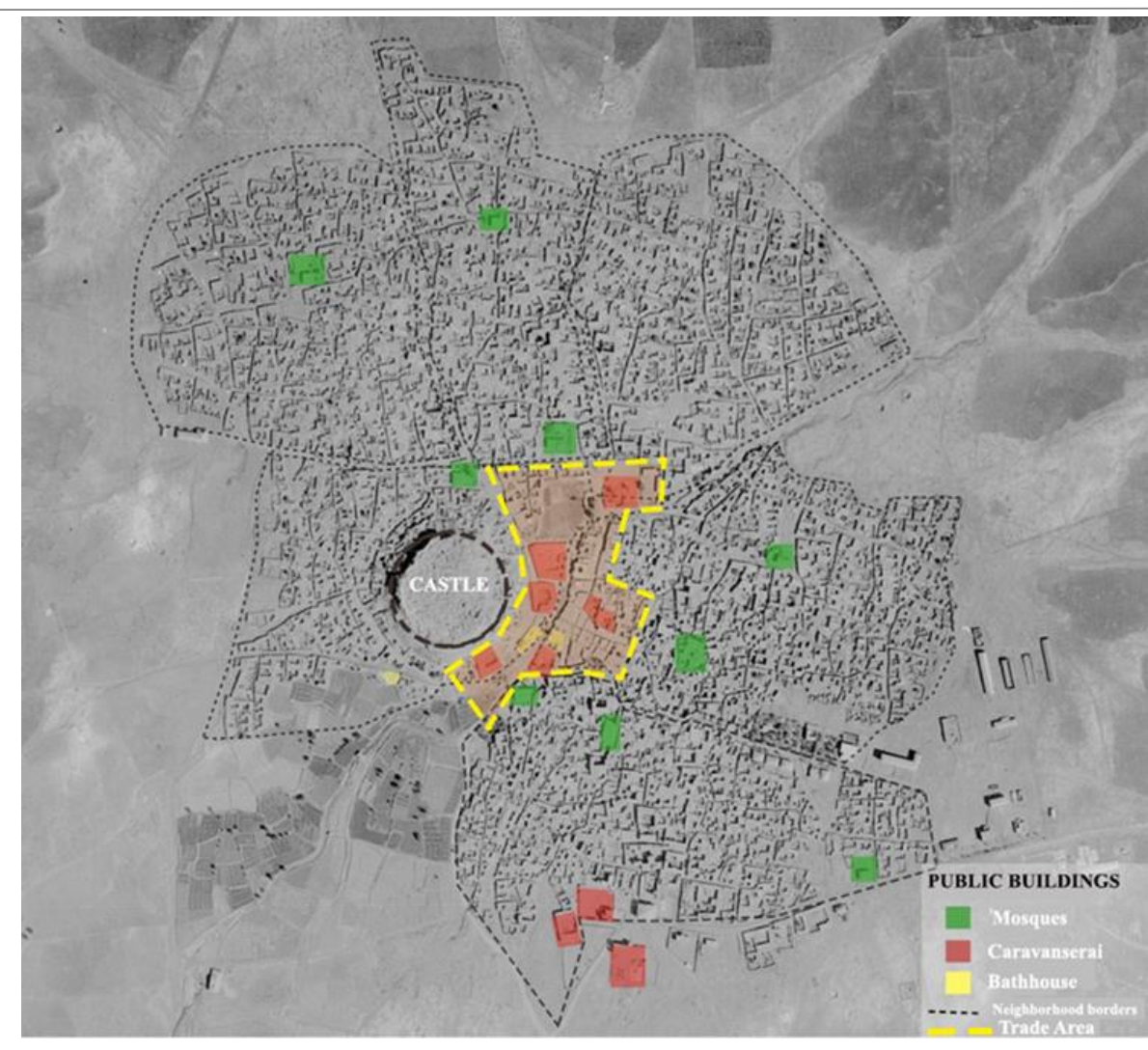

Baths and inns are arranged in a way that they are generally close and related. The mosques and coffeehouses have been important socializing places for men while the fountains built for the public use have been important for women's socialization. In the city where privacy is especially important for women, fountains have become an important means of communication (Kalak, 2018, p. 57). In the following section, squares and streets are analyzed as urban/public open spaces that form different hierarchical levels in the traditional settlement of Siverek.

\section{Squares}

Squares are open and large areas, most of which are surrounded by buildings, trees or natural boundaries (Hasol, 2017, p. 320) and public spaces that allow people to gather and interact in various ways (Erdönmez \& Akl, 2005, p. 68). Kuban draws attention to the absence of planned squares in the ancient Islamic and Turkish settlements. Open spaces around buildings served as such squares, and when people needed to gather, mosques, courtyards of mosques, and fountains met this need (Kuban, 1970, p. 210). The urban open spaces, which are socially important, did not emerge as city squares as observed in European cities. Apart from a few major monumental structures, the city did not have any structures designed holistically with their surroundings taken into account (Kuban, 1968, p. 70).

The squares in Siverek have a hierarchical order not by size but by intensity of use, and are generally developed in an organic form with the intersection of the roads. Therefore, it would perhaps be more precise to
Figure 6. Public structures and layout of the commercial texture (Edited by the Author) 
The Relationship Between the Public and Private Spaces in Siverek Traditional Settlement

call them as an "intersection" rather than a "square." Such areas formed by the intersection of alleys in Siverek neighborhoods are called a "Düz" (Akman, 2017, p. 156). Although they do not have the characteristics of a real square, they serve as the public areas where 'düz', mosques, grocery stores, coffee shops and fountains are located, small farmers' markets are set up, neighborhood weddings are held and problems related to the neighborhood are discussed. The main squares have been the areas used by all residents of the city (Figure 7).

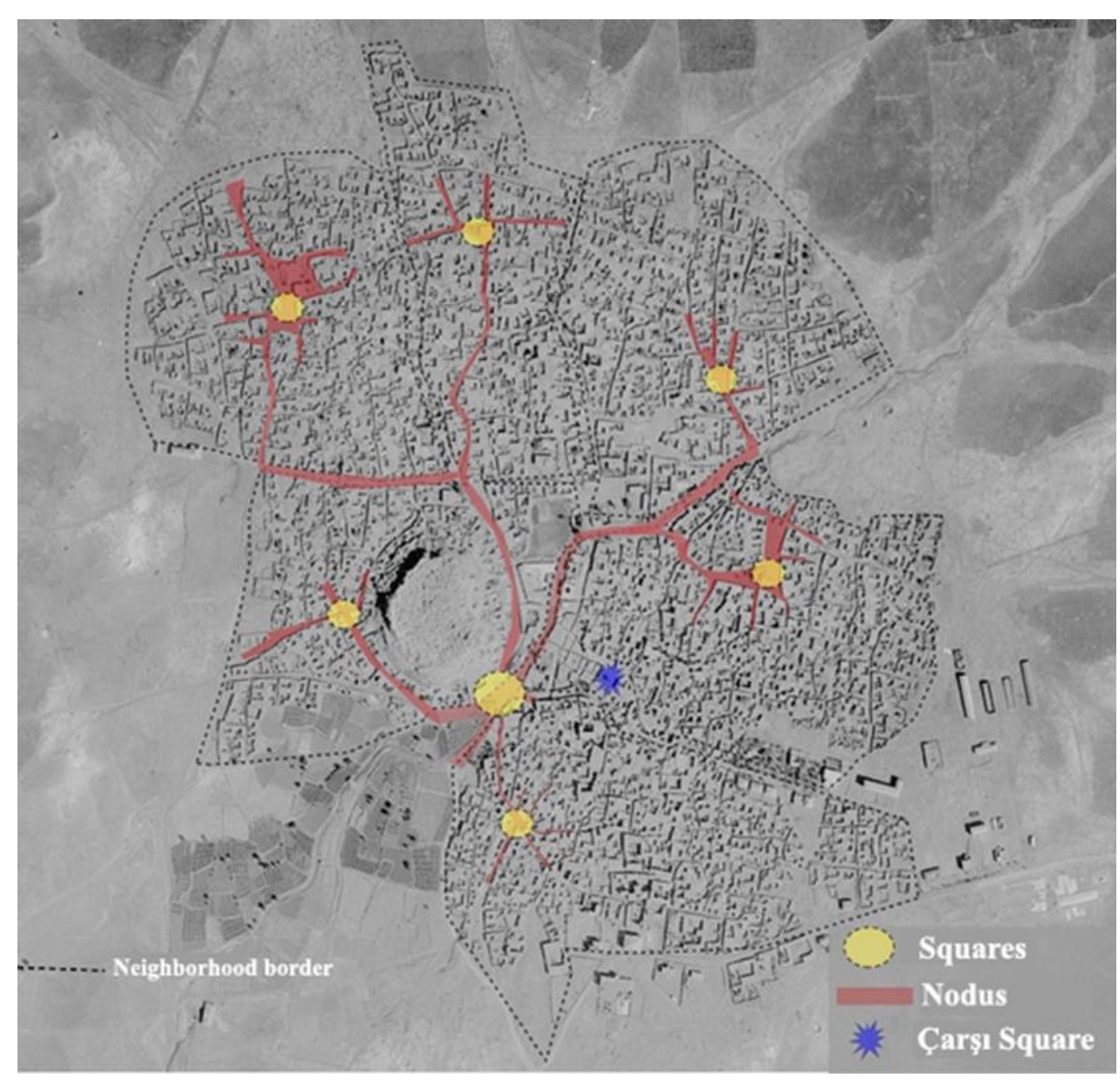

Figure 7: Square layout of Siverek settlement (Kalak, 2018, s. 84)

\section{Streets}

Streets are the main components of the public spaces that are the core of the city form (Tanyeli, 1987, p. 154-156). The streets that connect the spaces and buildings are the key elements connecting the empty and occupied spaces of a city. They also create the transitions and relationships between public, semi-public, semi-private, and private spaces. The streets in Siverek are called 'küçe' in the local dialect. "Küçe" is a Persian word meaning "street" (https://www.luggat.com/küçe/1/1). The streets in Siverek are in organic texture, narrow and curvilinear and include many dead ends. These streets have provided the relationship between spaces and people in the city with their archways, dead-end streets, the intersections formed by the intersection of the roads, and the narrowing and expanding spaces. 
Streets in the city have served as places where time is spent chatting, social assistance is provided, children played in safety, and where neighbors communicate with each other. Being narrow, the streets bordered by high windowless walls provide shady areas for a long time during the day. In the streets, where privacy is important, residential windows either do not open to the outside or open at the eye level. In the facade facing the street, there is almost no movement that will create any plastic effect other than the outer door movements (Kalak, 2018, p. 84). In the traditional Siverek houses, the doors opening to the street open in the opposite direction, thus blocking the view of neighboring houses' doors and allowing their privacy (Figure 8). This aims to cut off the visual contact when the door needs to be left open (Kalak, 2018, p. 107).

Siverek streets have a hierarchical order not by width but by the frequency of use. The dead-end streets, characterized as being intermediate spaces, serve as private spaces used only by certain people.

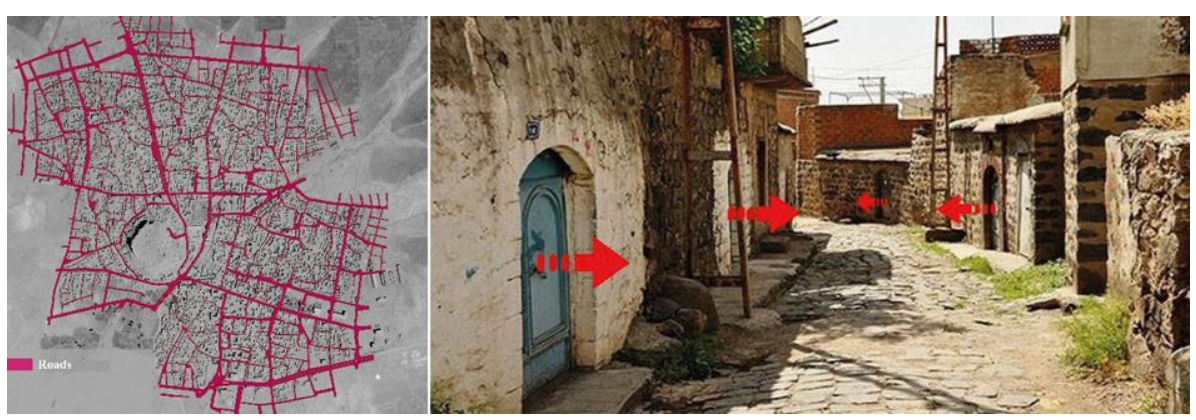

\section{In-between space, semi-public and semi-private space}

Public and private spaces are interdependent because they affect and shape each other. Rather than being sharply separated, they are connected by semi-public or semi-private spaces with different degrees of privacy and openness (Madanipour, 2003, s. 210). Semi-public and semi-private spaces are areas that can be viewed, observed, and inspected within the space hierarchy, ensuring the transition and continuity between public and private spaces. Habraken (1998) and Nooraddin (2002) argue that the controversial concepts of semi-public and semi-private fail to fully describe such spatial organizations, and propose 'in-between space' as a more inclusive and accurate definition of this concept (Nooraddin, 2002), (Habraken, 1998).

It is also described by terms such as intermediate space, threshold, and public/private space boundary. Forming the interior extensions of a building such as a bay window, balcony, portico, archade, patio, archway, and courtyard, this space not only creates an interface between public and private spaces, but also shapes social relations around the building. Intermediate spaces are distinct elements that shape traditional patterns by allowing spatial continuity. These elements can be attached to the private interior and the public exterior.
Figure 8. Siverek Street Network System and Street Connections (Kalak, 2018, s. 104) 
${ }^{1}$ Keleş states that the deadend street corresponds to the terms 'impase, cul-desac' in French, 'sackgasse' in German, and 'dead-end street' in English, and describes it as 'A closed road or place with only one exit, the other end of which is designed to protect residences and individuals from the noise of urban traffic and the concerns it creates' (Keleș, 1980, s. 34).
The Relationship Between the Public and Private Spaces in Siverek Traditional Settlement

For example, a courtyard connected to a street is a threshold that forms an intermediate space between the private space and the street (Doğan, 2016). Therefore, the cul-de-sacs and archways in the traditional Siverek residential texture can be described as intermediate spaces.

\section{Dead-end streets (Cul-de-sac)}

Dead-end streets (cul-de-sacs) ${ }^{1}$ are street connections that emerge as a result of many factors. Factors such as culture, social life, privacy, and irregular plot boundaries influence the formation of cul-de-sacs.

The existence of many cul-de-sacs in the organic texture of the city shows that the streets are an important part of the urban life. In the settlement with a radial layout, these dead end streets were built to have access to the houses, especially in the areas between the axes that widen as they get farther from the center. The dead-end streets, which are known as 'küçe çıkmaz' in the local dialect, have been places very busy with the hustle and bustle of daily life. While residential courtyards constitute the common living space of family life, the cul-de-sacs form the common area of the people living there. While the house itself, being shut off from the outside, ensures the household privacy, cul-de-sacs provide privacy for the residents. Such cul-de-sacs are critical especially for the socialization of women, who have only a limited public space. The activities such as wool washing, bread baking, street cleaning etc. that women do together are the indication that the cul-de-sac is used as a living space. In the studies carried out in Cami-i Kebir District, the intermediate spaces that are characterized by their role as a connection between the public and private spaces were analyzed, and the hierarchical order was thus explained clearly (Figure 9, Figure 10). 


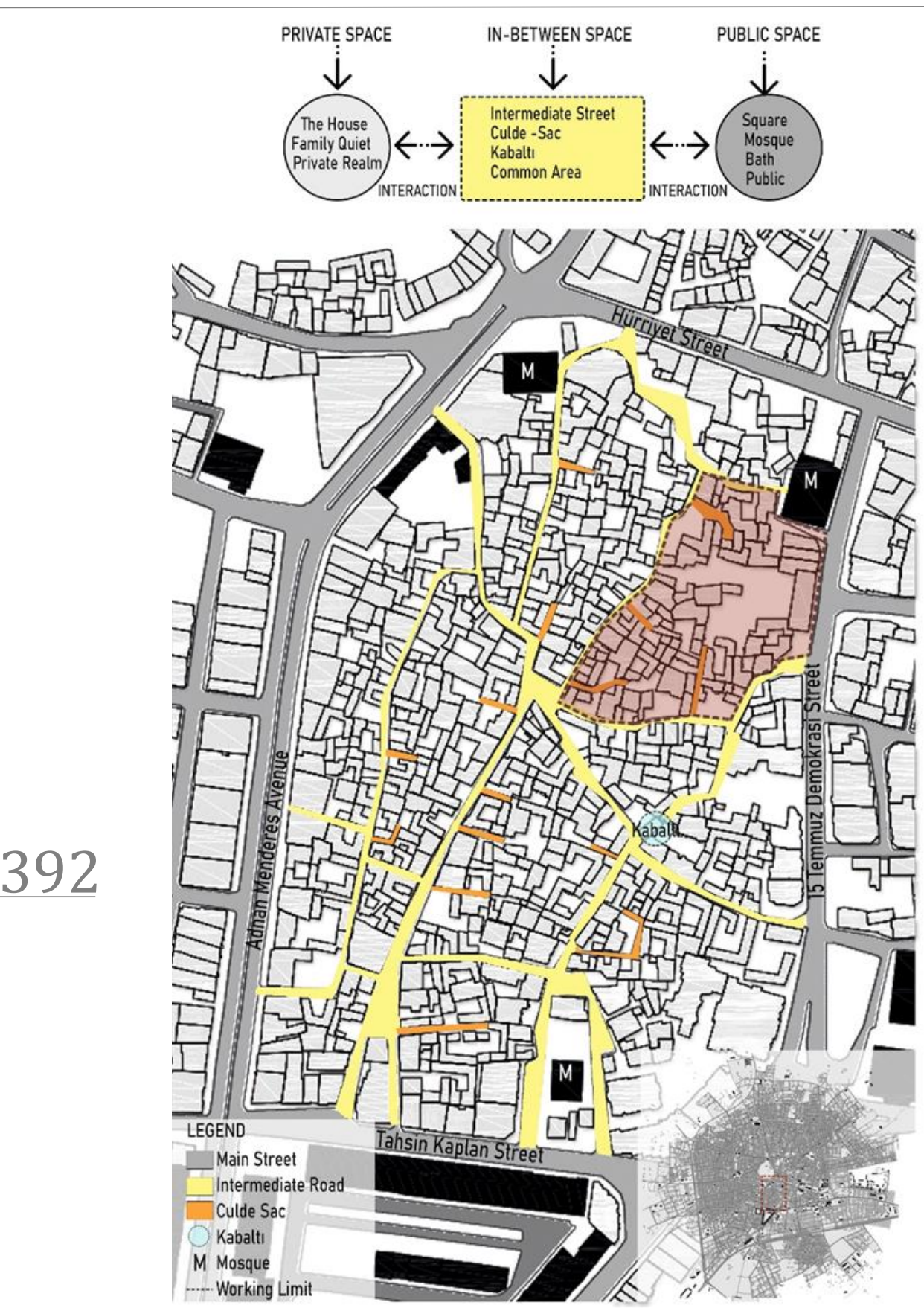

Figure 9. A drawing that shows the relationships among the roads in Cami-i Kebir District (Kalak, 2018, p. 91)

Although nothing blocks the entrances of the cul-de-sacs, these have not been places that are open to everyone. The cul-de-sacs, which form an invisible border monitored by the street residents, form a territoriality under the control of the residents living here. Although they are public space, they act as an intermediate space that allows the streets to run towards the houses and the houses towards the streets. At the same time, they serve as a threshold for the gradual transition from the public space of streets towards the private space of houses. 
The Relationship Between the Public and Private Spaces in Siverek Traditional Settlement

Figure 10. The cul-de-sac and residence relationship in Cami-i Kebir District (Kalak, 2018, p. 92)

Figure 11. Cul-de-sacs in the Cami-i Kebir District study area (Kalak, 2018, p.93)

${ }^{2}$ In the local architecture of Siverek, archways are known as "kantarma". Archways are named differently in different cultures. They are called 'abbara' or 'sabat' in Mardin city and its neighboring region.
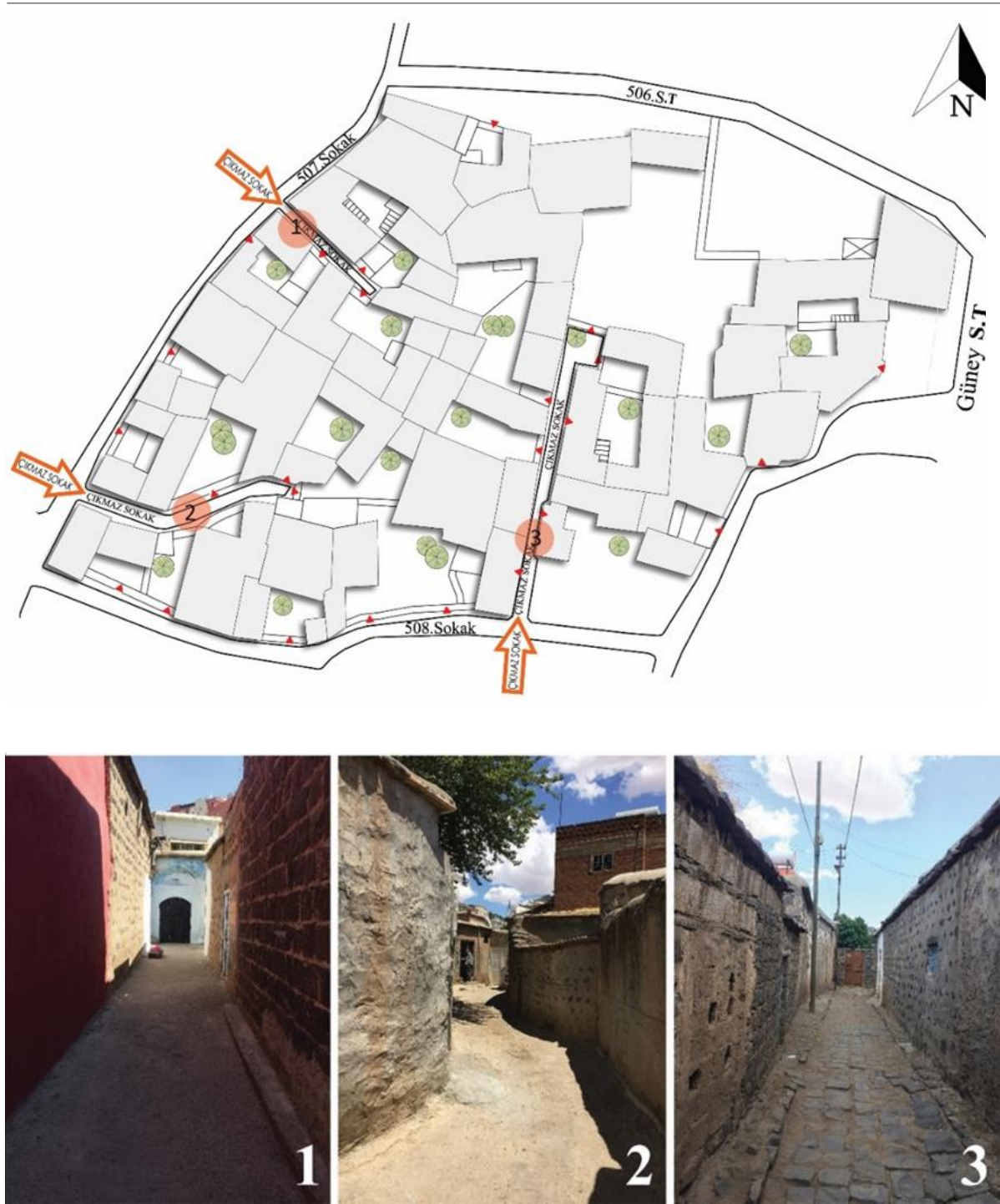

\section{Kabaltı (Archway)}

Kabalt $^{2}$ refers to a transit area where the upper level serves as a residence and the lower part is used as a street (Közcü , 2016, p. 8). The high number of such archways in the Southeastern Anatolia Region, where the Siverek district is located, has resulted both from an endeavor to gain extra space within the high building density of the traditional texture and an effort to create some cool shades to avoid the scorching sun. It has been developed in a region-specific way since the warmer climate of the region requires shaded areas. The two archways in Siverek have similar features. Bucak and Alhas archways are known by the names of the two important families that own these properties (Figure 12). 


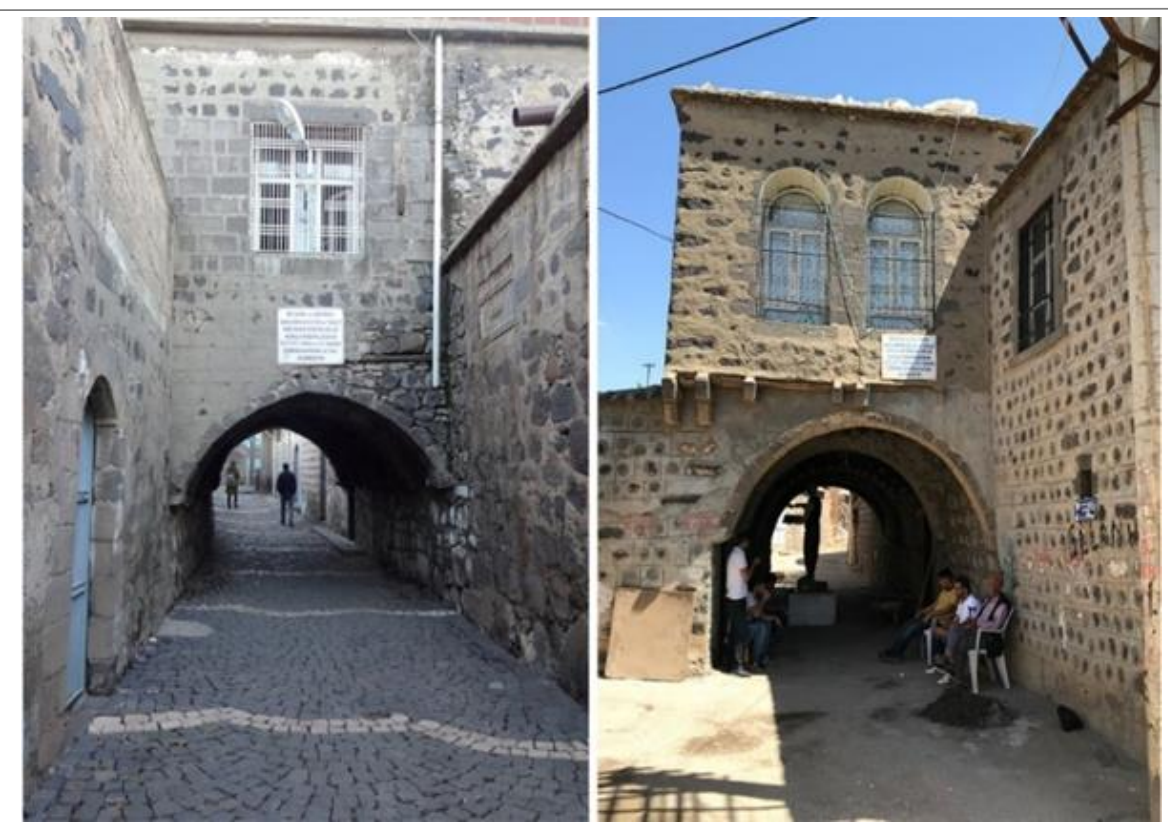

Archways have been important architectural elements that connect the house downstairs to the street and enables the house to interact with the street visually. The door of the house opens to the street under the archway. The archway is a different type of structure in which visual and auditory relations are established with public spaces. While the privacy of the house is ensured through the upper floor, the continuity of the street, which is open to public use, is ensured through the ground floor. Despite the street being a public space, due to the territoriality effect of the archwayed residence property ownership, the space under the archway also serves as an intermediate space that acts as a buffer zone or threshold between private and public spaces, rather than being purely public (Figure 13).
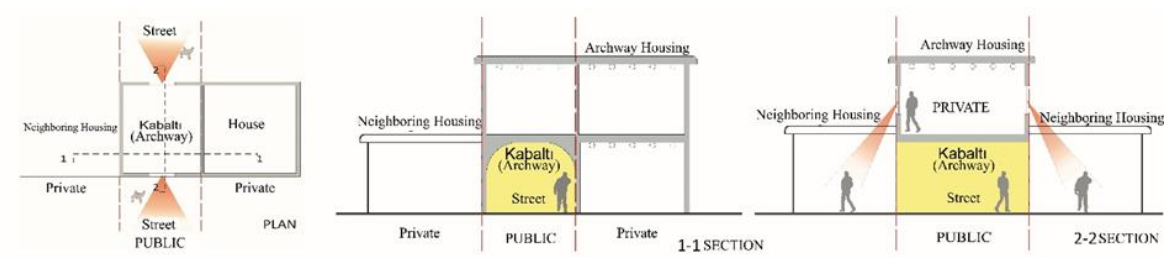

\section{Private Space - House in Siverek Settlement}

Houses are the private spaces where a family or individuals live, own and obtain adequate privacy from the public space. They reflect the character of the group to which they belong, representing the societies and individuals themselves, their culture, and lifestyle. Rapoport defines 'house' as the place where the form and organization are influenced greatly by the cultural environment to which it belongs and created according to the people's way of life. Siverek's traditional texture and houses are shaped by many factors such as lifestyle, culture, climate, geography, economy, ways of making a living, family structure and size, women's status, and understanding of privacy.
Figure 12. Bucak (left) and Alhas Archways

Figure 13. Schematic Illustration Describing the Principle of Archway (Kalak, 2018, p. 108) 
The Relationship Between the Public and Private Spaces in Siverek Traditional Settlement

Figure 14. Settlement Texture of Traditional Siverek Houses (Kalak, 2018, p. 103)

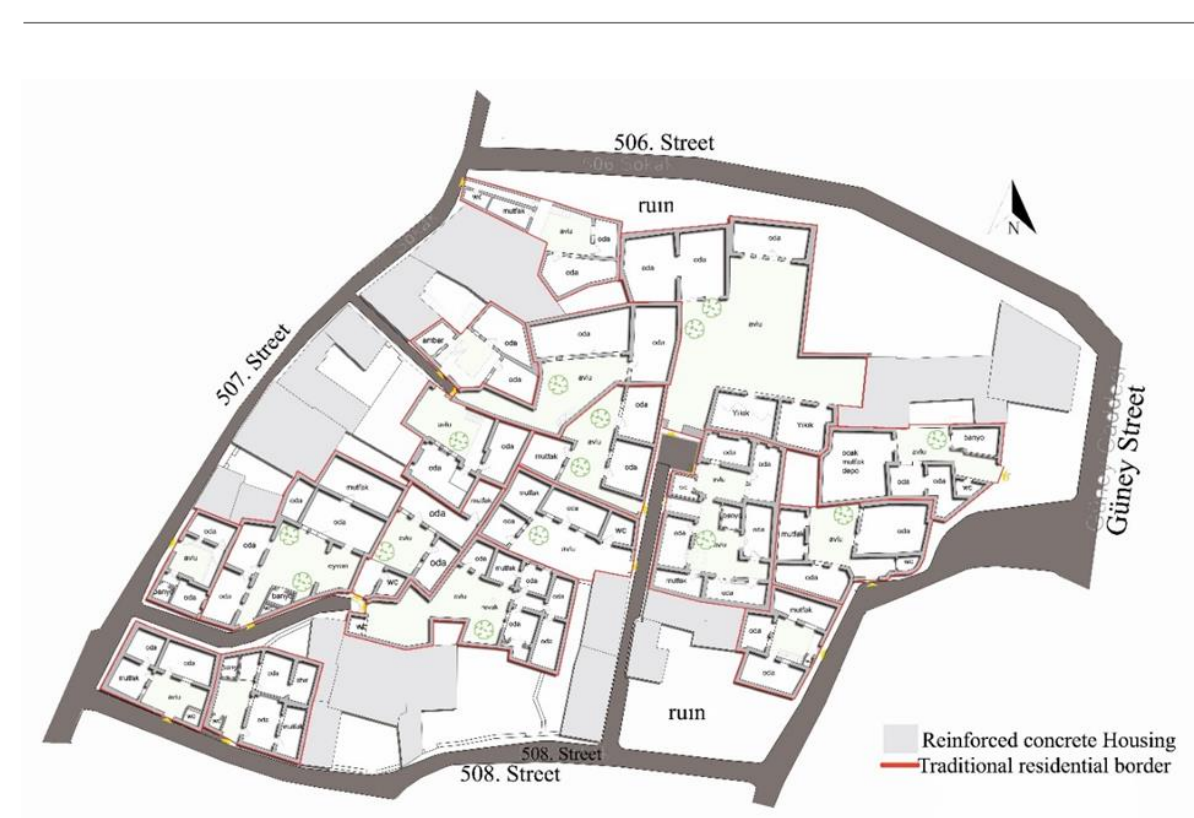

To analyze the Siverek houses, the Nigar Düzü area in the Cami-i Kebir District was selected in this study. 55 residential buildings in this area were surveyed and their spatial formations were examined (Figure 114). In light of these data, the relationship between the units that make up the house and its formation was analyzed. These units consist of barn, room, rooftop, restroom, furnace, and kitchen space grouped around the interconnected passage, courtyard and iwan, respectively, and are organized in a certain hierarchical order. This hierarchical order includes the grading that begins with the street entrance, which is the public space, and ends with the room unit, which is the most special space (Figure 15).

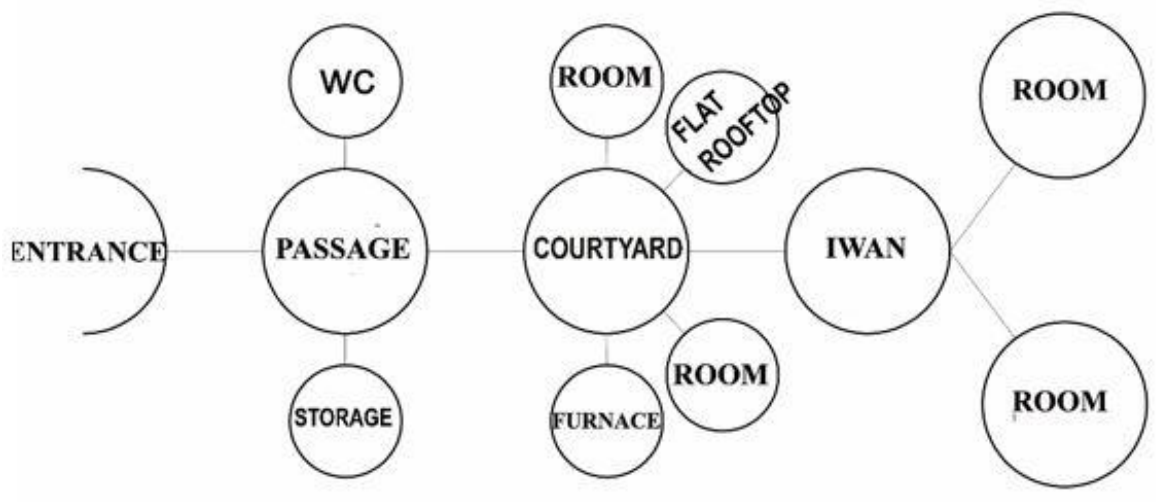

\section{Threshold (Passage)}

The door threshold (passage) is the area where relations between the indoors and outdoors are experienced. This area is also defined as an interface that allowing and easing the transition between the indoors and outdoors, between the public and private (Hillier \& Hanson, 1984). 
The concept of threshold and distances forming the threshold vary in every culture (Rapoport, 1969, p. 80).

It can be said that the passages at the entrance of Siverek houses are in the threshold position in the transition from public to private space. The entrance may directly open to the courtyard or entry can be allowed through the arches in the structure. In some houses, this section is designed in the shape of an ' $\mathrm{L}$ ' to weaken the visual link between the street and the courtyard. Thus, when the door is opened, the visual connection with the courtyard is cut off, and even when the door is left open, sufficient privacy for the courtyard is ensured (Kalak, 2018, s. 109). In most of the houses the restroom is located inside these passages that are close to the street (Kalak, 2018, p. 114).
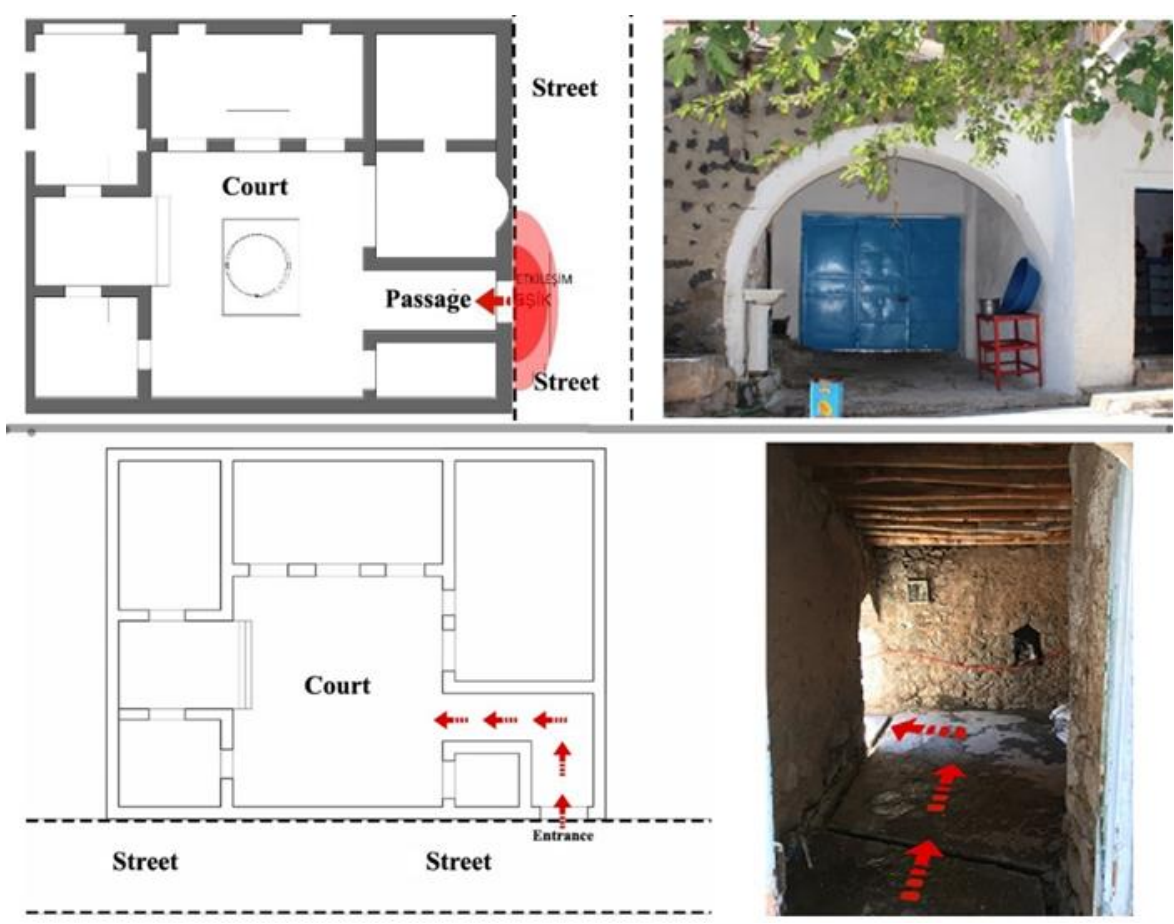

\section{Courtyard}

In the traditional Siverek houses, the most important unit of organization is the courtyard, around which the other units cluster. It also plays a key role in the residential hierarchy with its gathering and distributing function. All spaces of the house that communicate with the outside open to the courtyard. The summer units are located to the south of the courtyard. The façade of the summer units face north to provide shade. The winter units are usually located to the north of the courtyard. Built to face south, the façades of these winter units let the daylight in. The washing, resting, cooking etc. activities are performed in the courtyard where the pool, well and landscape elements are located. The courtyard is a place used as an open room in summer. While the trees in the courtyard create a shady area to protect from heat, they also contribute to ensuring climatic comfort by creating moisture.
Figure 16. House-passage relationship in traditional Siverek houses (Kalak, 2018, p. 115) 
The Relationship Between the Public and Private Spaces in Siverek Traditional Settlement

The courtyard, which is also used as a socializing place, can be considered as the most active area of the house. Besides being a place for all household members to communicate with and host guests, this area also serves as a playground for children and provides an outdoor space especially for women who spend their time in closed areas (Kalak, 2018, p. 115).

Figure 17. The Courtyard (Kalak, 2018, p. 115).
Figure 18. An example of the traditional Siverek Iwan and a schematic drawing of it (Kalak, 2018, p. 118)

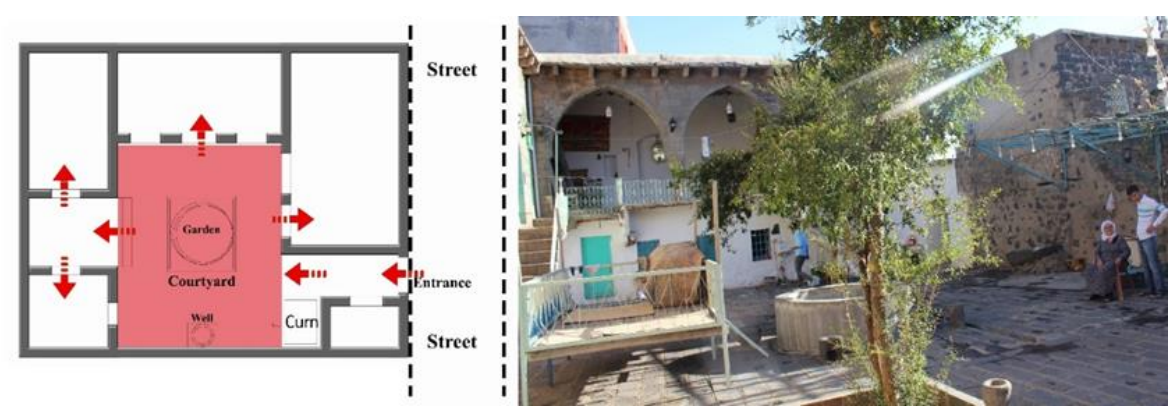

\section{Iwan (A vaulted or domed space recessed from a central hall or court)}

The iwans, which are usually between the rooms, covered on top and on three sides, facing the courtyard, are the places that are used extensively in the summer. This space was designed to have an arch and at a higher grade from the courtyard (Kalak, 2018, p. 116). The iwans, which are generally on the ground floor, are accessed to the ones on the first floor mostly by the stairs connected to the courtyard. The iwan is a semi-open space between the closed room and the open courtyard, it is located in the summer section of the building, and most of the household activities are performed in this area in the summer. The grade of iwans as a private space is higher than the courtyards and lower than the rooms, and thus can be considered as a threshold in the house. The iwan is usually found in the houses owned by high income families.
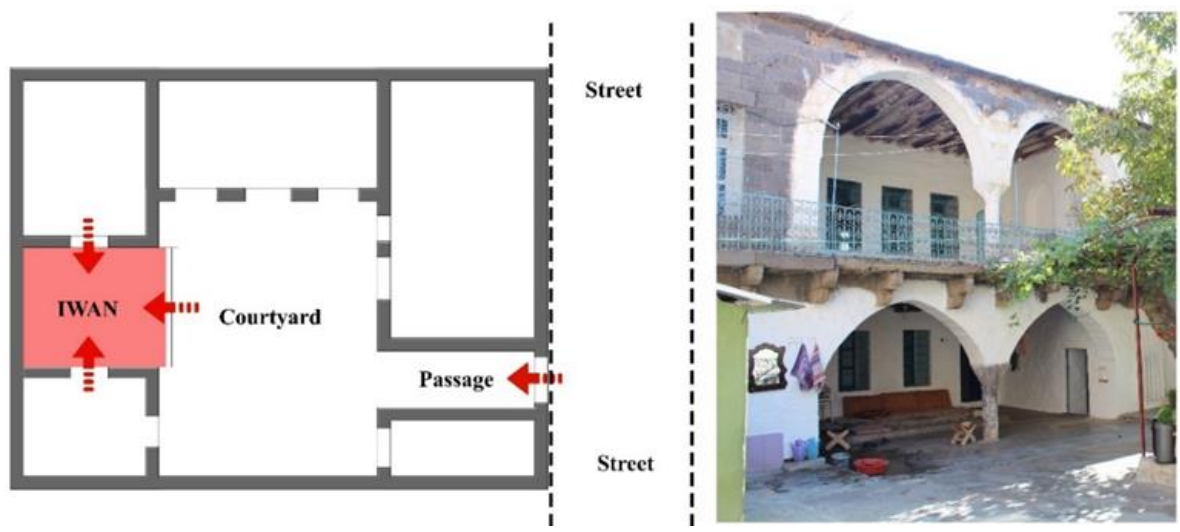

\section{Room}

In the traditional Siverek houses, rooms are multifunctional and nonspecialized spaces. Different functions such as sitting, resting, eating, sleeping, welcoming guests, and bathing are organized to occur in the same space. However, in some large houses, especially in those owned by high-income families, there are some specialized spaces for various 
functions as well. Due to climatic factors, these have summer and winter rooms, with the summer rooms facing north and the winter rooms facing south. Taking advantage of their thickness, the traditional Siverek residential walls were built to have some alcoves and niches. Quilts, mattresses and pillows laid on the floor for sleeping at night are placed in an alcove in the wall during the day.

The rooms can be described as the most private and important places in the hierarchy within the house, after the courtyard that is open to everyone and the iwan that is customized according to the courtyard. The room windows open to the iwan or courtyard, which reflects the inward perspective towards the building.

To ensure privacy, some rooms are separated as 'haremlik' (womenonly room) and 'selamlik' (men-only room) in some houses. Thus the most important room of the house is the 'selamlık,' also used as the main room. There is a difference in terms of spatial hierarchy due to the fact that 'selamlik' in traditional houses is also a place of living and hosting for men, and the 'haremlik' is used only by women. The 'haremlik' is considered as a more special area because it is kept more secret and closed (Kalak, 2018, p. 119).
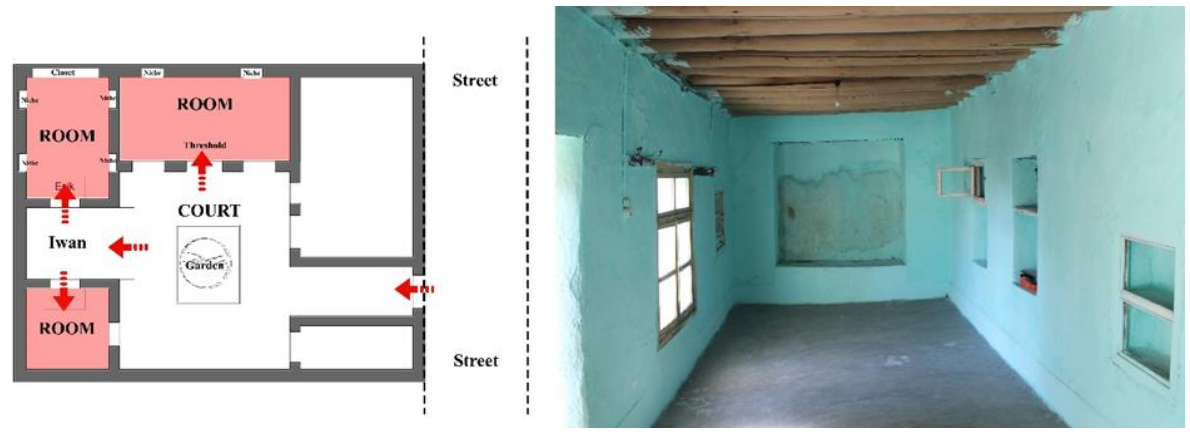

\section{Flat Rooftop (Dam)}

One of the characteristic features of the Siverek house is its flat adobe rooftops made of earth to ensure heat insulation. These rooftops are obtained by pouring and compacting $30-50 \mathrm{~cm}$ of soil on the ground formed with round wooden beam poles. In the summer, when the coolness of the courtyard is not enough in hot weather, the adobe rooftops are used for sleeping purposes (Kalak, 2018, p. 120). The rooftop is also an important place for drying vegetables for consumption during the winter. Compared to the other open space, the courtyard, it appears to have a lower level of privacy. It is observed that although residential privacy from the public space is ensured, the use of such roofing prevents privacy from the neighboring houses. Since the roofs of neighboring houses are adjacent, there are no physical obstacles to block transition from one rooftop to another, but neighbors do not step on each others' rooftops without permission (Kalak, 2018, p. 121).
Figure 19. A traditional Siverek room and its schematic drawing (Kalak, 2018, p. 120) 
Figure 20. A visual depicting the life on the roof in houses with the traditional earthen roofs (Dalkılıç \& Bekleyen, 2011, p. 430)
The Relationship Between the Public and Private Spaces in Siverek Traditional Settlement

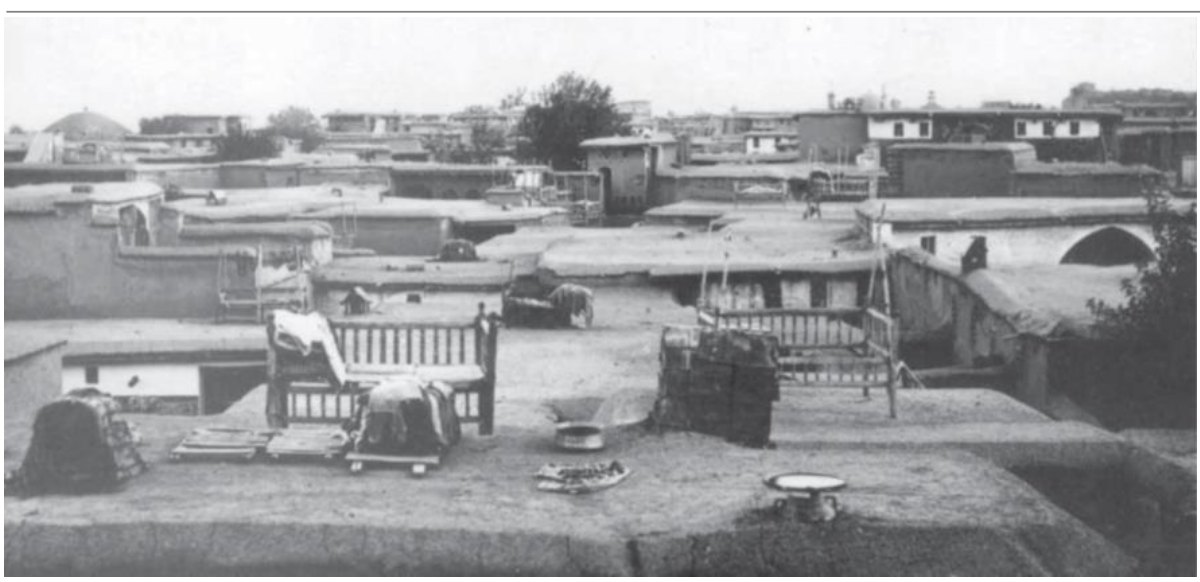

\section{Service Spaces}

In the traditional Siverek houses, the kitchen, pantry, and restroom, and in some houses, the bathroom and barn form the service areas. The kitchen exhibits no architectural elements except for the stove, chimney and wall niches. Access to the kitchen is provided from the courtyard and its façade is associated with the courtyard. While preparing and cooking food takes place in the kitchen during the summer months, the preparation processes are done in the rooms and the cooking is done in the kitchen during the winter months due to the cold weather. While the cooking stove is usually located in the kitchen, it may also be in the passage section of some residences. In the households with high income level, the areas where food is cooked and prepared for service are designed as two different places (Kalak, 2018, p. 122). The pantry section is either close to or within the kitchen.

In the traditional Siverek houses, a bathing place is not designed as a separate space, and the bathing takes place mostly in the rooms. High income houses may have a separate Turkish bath as well. Three Turkish baths (Abdal Ağa, Yer Altı and Cincıklı Baths) are the primary venues that meet most bathing needs of the city (Kalak, 2018, p. 123).

To prevent possible problems by keeping the sewage pipe length short, the restrooms are generally positioned near a street, in the passages where the houses are entered. In addition, due to Islamic beliefs, these restrooms are built to make sure that they do not face South, which is the direction towards the Qibla.

Some barns have been built because some families make their living by raising livestock, ride horses, and use beasts of burden. Some of these are located near the residential entrance and some are located behind the house, which are accessed through the main room (Kalak, 2018, s. 124).

\section{CONCLUSION}

This study discusses the original spatial elements that have shaped the traditional urban texture of Siverek surviving intact to a great extent by examining their hierarchical order. It was observed that there is a continuous hierarchical order between the spaces from the space with 
the highest publicity in the city center to the private space with the highest degree of privacy in the house (Figure 21, Figure 22).
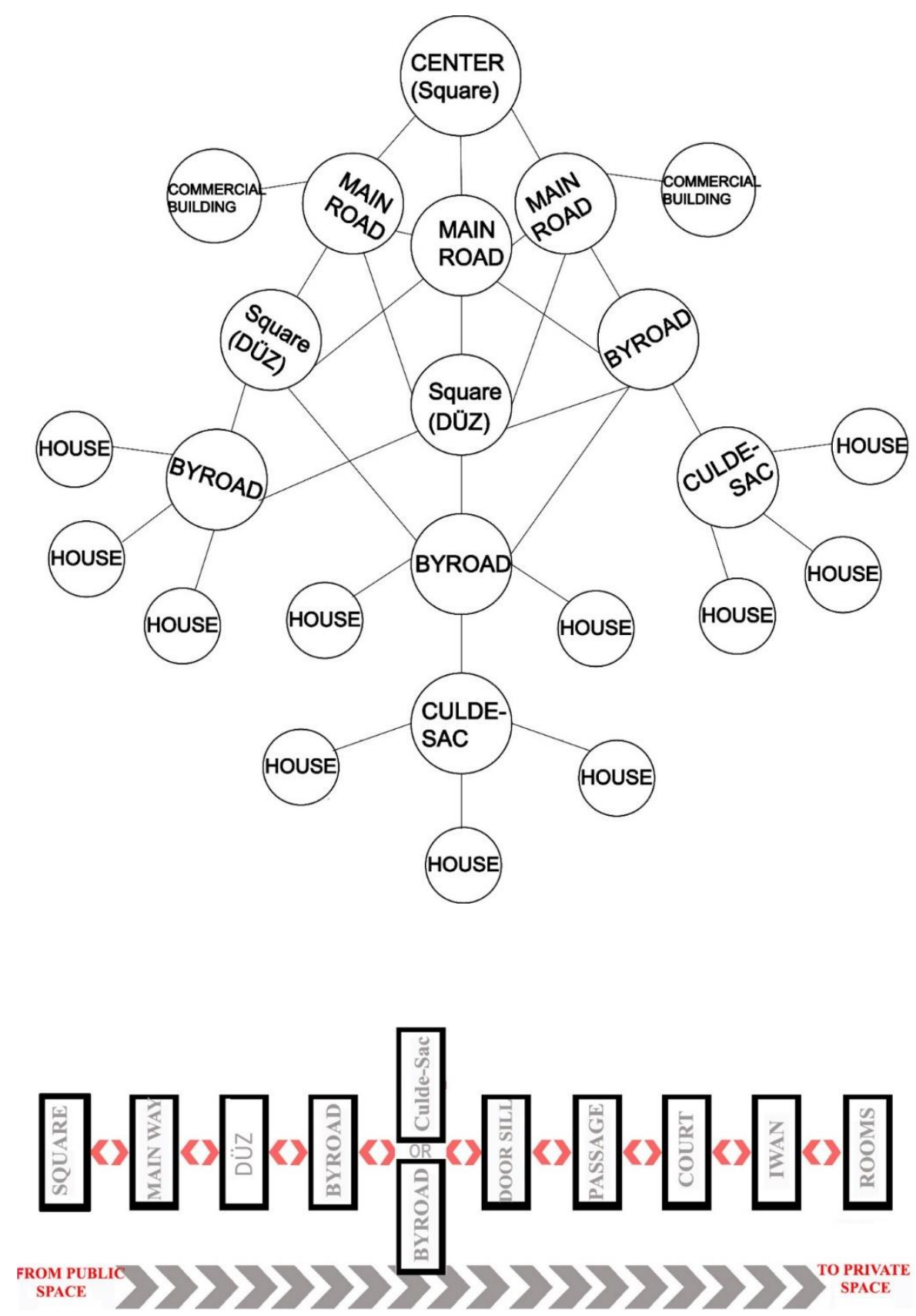

This hierarchical order is unique to the region and seems to have a partially different fiction compared to the traditional settlements of the Ottoman period in Anatolia. Here, kabalti (archway), passage and dam (flat rooftop) are additional steps in Siverek's hierarchical spatial fiction. In addition, the function of the courtyard also makes a significant difference. The courtyard, which is an open version of the sofa in traditional Turkish residences, organizes the transition from the common area of the residence, which is a private space, to the rooms, while also forming a step in the hierarchical transition between the open space and the indoor space. In this aspect, it differs from the
Figure 21. The hierarchical order of the city (Edited by the Author)

Figure 22. Grading from the square to the room (Edited by the author, Kalak, 2018) 
The Relationship Between the Public and Private Spaces in Siverek Traditional Settlement

garden, which is bordered by high walls and has a similarly introverted layout.

These spatial formations, which are the product of hundreds of years of cultural accumulation and experience, are disappearing day by day as a result of miscalculated interventions, delayed conservation measures, wrong decisions and inappropriate solutions, and thus cannot be transferred to the future and thus ensure cultural continuity. There are two main problems here. The first is the problem of preserving the historical traditional texture. Today, conservation work in this area remains limited to some monuments and individual structures that do not properly address the risk that threatens the traditional texture dominated by modern structures. The other major problem is the rapid destruction of the traditional urban fabric by the modern texture. In both new development areas and demolished structures in the old texture, we encounter grid system and multi-storey structures that are incompatible with traditional texture and scale. This approach also disrupts the hierarchical order of public and private spaces. The behavioral, cultural, social, economic, geographical and climatic factors that shape the traditional spatial elements still exist today. This problem can be solved by preserving the spatial elements of the traditional texture and the hierarchy of the public and private spaces by considering them within a broader scale of texture. Therefore, it is critical to include the spatial features of the traditional Siverek house in the new building design processes. Thus, not only the existing traditional texture and the architectural elements that make up this texture will be preserved, but also the architectural values will be transferred to the future generations by reflecting the urban character to the new designs.

\section{ACKNOWLEDGEMENTS/NOTES}

This study is an excerpt from the master's thesis entitled 'The spatial elements that form the siverek traditional settlement' conducted by Rana karasözen, prepared by Mazlum KALAK.

\section{FINANCIAL DISCLOSURE}

The authors declared that this study has received no financial support.

\section{CONFLICT OF INTEREST}

No conflict of interest was declared by the authors.

\section{ETHICS COMMITTEE APPROVAL}

Ethics committee approval was not required for this article.

\section{LEGAL PUBLIC/PRIVATE PERMISSIONS}

Necessary legal permissions were obtained for research in this study. 


\section{REFERENCES}

Akpirinç, H. H. (2012). Siverek İlçe Merkezinin Coğrafi Etüdü (Yüksek Lisans Tezi). Kahramanmaraş: Kahramanmaraş Sütçü İmam Üniversitesi.

Aydemir, Ş. (2004). Kentsel Arazi Kullanım Modelleri Ve Fizksel Gelişme Formlar. Ş. Aydemir, S. Aydemir, D. Şen Beyazlı, Ö. Nermin, A. M. Öksüz, S. Cenap, ... Y. Aydın Türk içinde, Kentsel Alanların Planlanması ve Tasarımı (s. 119-140). Trabzon: Akademi Kitabevi.

Çelik, B. (2008). Arkeolojide Urfa. İstanbul: Şanlıurfa Valiliği İl Kültür ve Turizm Müdürlüğü Yayınları.

Doğan, H. (2016). The Interaction Between Public and Private Space inTraditional Environments: The Case of KabaltıHouses in Urfa. Yüksek Lisans Tezi. Gazimağusa, Kuzey Kıbrıs: Doğu Akdeniz Üniversitesi.

Erdönmez , M., \& Akl, A. (2005). Açık Kamusal Kent Mekanlarinin Toplum İlişkilerindeki Etkileri. Megaron, 1(1), 67-87.

Erdönmez, M. (2005). . Açık Kamusal Kent Mekanlarının Toplumsal İlişkileri Yapılandırmadaki Rolü, Büyükdere - Levent - Maslak Aksı. Doktora tez.İstanbul: Yıldız Teknik Üniversitesi.

Eyüce , A. (2005). Geleneksel Yapılar Ve Mekanlar. İstanbul: Birsen Yayınevi.

Gökgür, P. (2008). Kentsel Mekanda Kamusal Alanın Yeri. İstanbul: Bağlam Yayıncılık.

Grosz, E. (2001). Architecture from the outside: essays on virtual and real space. Cambridge : MIT Press.

Gürallar, N. (2009). Kamu - Kamusal Alan - Kamu Yapıları - Kamusal Mekân: Modernite Öncesi ve Sonrası için Bir Terminoloji Tartışması. Mimarlık Degisi 350, 52-55.

Habraken, N. (1998). The Structure of the Ordinary: form and control in the built environment. Cambridge Mass: MIT Press.

Hasol, D. (2017). Ansiklopedik Mimarlık Sözlüğü. İstanbul: Yem Yayın.

Hillier, B., \& Hanson, J. (1984). The Social Logic of Space. Cambridge: Cambridge University.

Kalak, M. (2018). Siverek Geleneksel Yerleşimini Biçimlendiren Mekansal Ögeler. Eskişehir. Yüksek Lisans Tezi: Anadolu Üniversitesi.

Kandemir, Ö. (2017). Architectural and Urban Identity Transformation of Eskisehir. IOP Conf. Series: Materials Science and Engineering , 245.

Karaman, A. (1991). Karaman, A. (1991). Toplu Konut Alanlarının Tasarımında Sosyo-Kültürel Veriler: Bazı İlke ve Ölçütlerin İrdelenmesi. Yapı Dergisi(118), 35-41.

Keleș, R. (1980). Kentbilim Terimleri Sözlüğü. Ankara: Türk Dil Kurumu Yayınları. 
The Relationship Between the Public and Private Spaces in Siverek Traditional Settlement

Közcü , H. (2016). Urfa Mimarisinde Kabaltılar. (N. Karadağ, Dü.) Şanlıurfa: Şanlıurfa Büyükşehir Belediyesi.

Kuban, D. (1968). Anadolu Türk Şehri, Tarihî Gelişmesi, Sosyal ve Fizikî Özellikleri. Vakıflar Dergisi, 53-73.

Kuban, D. (1970). 100 Soruda Türkiye Sanat Tarihi. İstanbul: Çağdaş Yayınları.

Madanipour, A. (1996). Design of Urban Space. An Inquiry into a Sociospatial Process. UCL DISCOVERY, 23(2), 158.

Nooraddin, H. (2002). In-between space: Towards establishing new methods in Street Design. Global Built Environment Review, 50-57.

Özgültekin, R., Akman, E., Demirbağ, H., \& Sun, K. (2003). Tarihi ve Kültürüyle SIVEREK. Ankara: Siverek Kaymakamlığı Yayınları.

Rapoport, A. (1969). House Form And Culture. New Jersey: Prentice Hall.

Rapoport, A. (1977). Human Aspects of Urban Form. Oxford: Pergamon Press.

Sennett, R. (2002). Kamusal insanın Çöküşü. İstanbul: Ayrıntı Yayınları.

Sinmaz, S., \& Ahsen Özdemir , H. (2016). Türkiye Şehir Planlama Pratiğinin Kentsel Morfoloji ve Tipoloji Üzerindeki Etkileri, Siverek Kenti İçin Bir Değerlendirme. İdeal Kent(18), 8-33.

Tanyeli, U. (1987). Anadolu-Türk Kentinde Fiziksel Yapının Evrim Süreci (11.-15.yy). İstanbul: Doktora Tezi: İTÜ Mimarlık Fakültesi.

\section{Resume}

Mazlum Kalak received his MS degree from Anadolu University in the major of architecture. He currently works as a research assistant in the Architecture Department of Gazi University. He continues his education as a doctorate student in the field of Architecture.

Rana Karasözen received her MS degree from Anadolu University and Ph.D from Istanbul Technical University. She currently works at Eskişehir Technical University, Department of Architecture, as an associate Prof. of History of Architecture. 